\title{
Carbon Assimilation Pathways during Growth of Pseudomonas AM1 on Methylamine and Pseudomonas MS on Methylamine and Trimethylsulphonium Salts
}

\author{
By C. WAGNER* AND J. R. QUAYLE \\ Department of Microbiology, University of Sheffield, Sheffield, SIo $2 T N$
}

(Received 24 March I972; revised 2 May 1972)

\begin{abstract}
SUMMARY
A study was made of the incorporation of carbon from $\left[{ }^{14} \mathrm{C}\right]$ methylamine by cultures of Pseudomonas AMI growing on methylamine. The distribution of radioactivity within the non-volatile constituents of the ethanol-soluble fractions of the bacteria, after incubation for periods of up to $38 \mathrm{~s}$, was analysed by chromatography and autoradiography. Most of the radioactivity fixed at the earliest times of sampling appeared in serine, phosphorylated compounds and malate. These results contrasted with previous studies of the incorporation of labelled growth substrates by cultures of Pseudomonas Ms growing on methylamine or trimethylsulphonium salts and correlated with the specific activities of hydroxypyruvate reductase, phosphoenolpyruvate carboxylase, $N$-methyl glutamate synthetase and $\gamma$-glutamylmethylamide synthetase in bacterial extracts. No hydroxypyruvate reductase was detectable in extracts of Pseudomonas Ms grown either on methylamine or on trimethylsulphonium nitrate. The assimilation pathway for methylamine in Pseudomonas AMI appears essentially the same as that for methanol and different from that in Pseudomonas MS.
\end{abstract}

\section{INTRODUCTION}

The group of bacteria capable of aerobic growth on $\mathrm{C}_{1}$ compounds includes two species which can grow at the expense of methylamine: Pseudomonas AMI and Pseudomonas Ms. Growth of Pseudomonas AMI on methanol involves serine as an early product of methanol metabolism (Large, Peel \& Quayle, I96I). Growth of Pseudomonas AMI on methylamine has been assumed to involve a similar assimilation pathway to that for methanol because mutants lacking the following enzymes of the serine pathway are unable to grow on either methanol or methylamine: hydroxypyruvate reductase (Heptinstall \& Quayle, 1970); serineglyoxylate aminotransferase (Harder \& Quayle, I97I); glycerate kinase (Anthony, Dunstan \& Drabble, I97I). By contrast, when Pseudomonas MS was grown on methylamine, serine was not found to be an early product of $\mathrm{C}_{1}$ assimilation; instead, incubation of intact bacteria with radioactive methylamine resulted in the rapid formation of two unusual amino acids: $N$-methylglutamate and $\gamma$-glutamylmethylamide (Kung, r969; Kung $\%$ Wagner, I969). The former compound was first identified as an early product of methylamine incorporation in a related species of Pseudomonas by Shaw, Tsai \& Stadtman (I966). These investigators also described the enzyme reaction responsible for the synthesis of $N$-methylglutamate. The reaction responsible for the biosynthesis of $\gamma$-glutamylmethylamide was described by Kung \& Wagner (1969) and both of these enzymes were shown to be

* Present address: Veterans Administration Hospital, Department of Microbiology, I3 Io Twenty Fourth Avenue South, Nashville, Tennessee 37203, U.S A. 
induced in Pseudomonas MS when grown on methylamine (Kung, 1969; Kung \& Wagner, I969).

These results suggest that Pseudomonas AMI and Pseudomonas MS grow on methylamine by two different assimilatory pathways and call for confirmation by determination of the early products of methylamine assimilation by Pseudomonas AMI and comparison of the levels of key enzymes for the incorporation of $\mathrm{C}_{1}$ compounds in both Pseudomonas AMI and Pseudomonas Ms. This paper records the results of such a study.

Growth of the organism

METHODS

Pseudomonas AMI was grown on methylamine as described by Heptinstall \& Quayle (1970). Pseudomonas MS was grown as described by Kung \& Wagner (1970).

\section{Preparation of tracer solutions}

$\left[{ }^{14} \mathrm{C}\right]$ Methylamine hydrochloride was purchased from the Radiochemical Centre, Amersham, Buckinghamshire. It was purified before use by vacuum distillation of $\left[{ }^{14} \mathrm{C}\right]-$ methylamine released from the hydrochloride by treatment with sodium hydroxide.

\section{Incorporation of $\left[{ }^{14} \mathrm{C}\right]$ methylamine by whole cells}

Cultures of methylamine-grown bacteria in the exponential growth phase were centrifuged and resuspended at $4 \mathrm{mg}$ dry wt/ml in $9 \mathrm{ml}$ of a solution containing $10 \mathrm{mM}-\mathrm{Na} / \mathrm{K}$

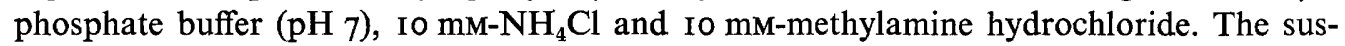
pension was placed in a cylindrical glass vessel $(10 \mathrm{~cm} \times 2.5 \mathrm{~cm}$ diam.) with a sintered glass bottom and was aerated at $20^{\circ} \mathrm{C}$ by blowing air through the sintered glass. After 5 min aeration, I ml of a solution of $\left[{ }^{14} \mathrm{C}\right]$ methylamine hydrochloride $(6 \cdot 25 \mu \mathrm{mol}$ containing $200 \mu \mathrm{Ci}$ of ${ }^{14} \mathrm{C}$ ) was added and samples (approx. I ml) were withdrawn at suitable time intervals with a hypodermic syringe and squirted into $4 \mathrm{ml}$ of aqueous $95 \%(\mathrm{v} / \mathrm{v})$ ethanol at room temperature. A control incubation with $\mathrm{I} \mathrm{ml}$ of a boiled bacterial suspension and a proportional volume of tracer solution was performed and subsequently treated in the same way as the samples obtained from the live incubation.

\section{Preparation of samples for chromatography}

The ethanolic samples of killed organisms were centrifuged and the resulting precipitates extracted with $0.2 \mathrm{ml}$ of aqueous $20 \%$ (v/v) ethanol. The combined supernatants were evaporated to dryness at $40^{\circ} \mathrm{C}$ under reduced pressure and taken up in $0.2 \mathrm{ml}$ of water. Each sample was transferred to the top of a column $(2 \mathrm{~cm} \times 0.5 \mathrm{~cm}$ diam.) of Amberlite CG $\mathrm{I} 20$ (I00-200 mesh: $\mathrm{H}^{+}$form) and eluted with $2 \mathrm{ml}$ of $2 \mathrm{M}-\mathrm{NH}_{4} \mathrm{OH}$ to displace cationic species of less basicity than $\mathrm{CH}_{3} \mathrm{NH}_{3}{ }^{+}$(Shaw et al. 1966). The eluates were again evaporated to dryness at $40{ }^{\circ} \mathrm{C}$ under vacuum and taken up in $0.2 \mathrm{ml}$ of aqueous $20 \%$ (v/v) ethanol.

\section{Chromatography and radioautography}

The methods of chromatography, autoradiography and identification of labelled compounds were as described by Large et al. (196I), unless specified otherwise.

Succinic, fumaric, citric and isocitric acids were identified by two-dimensional cellulose thin-layer co-chromatography in the system described by Myers \& Huang (1969). Citric and isocitric acids were also identified by co-electrophoresis on Whatman 3 MM paper for $45 \mathrm{~min}$ at a potential gradient of $40 \mathrm{~V} / \mathrm{cm}$ in a buffer system consisting of $0.5 \mathrm{M}$-acetic acid adjusted to $\mathrm{pH} 4$ with pyridine (Gross, 1959). Aspartic acid, glutamic acid, serine and 
glycine were separated and identified by electrophoresis under similar conditions as described above except that the following two buffer systems were used: formic acid-water $(\mathrm{I}: 37 \cdot 5, \mathrm{v} / \mathrm{v} ; \mathrm{pH} 2)$; pyridine-acetic acid-water $(200: 8: 2792$, by vol.; $\mathrm{pH} 6 \cdot 4)$.

\section{Measurement of radioactivity}

The radioactivity on paper chromatograms was measured with a mica end-window G.M. tube (Large et al. 196I), appropriate corrections being made for background counts.

\section{Preparation of bacterial extracts}

For the measurement of hydroxypyruvate reductase and phosphoenolpyruvate carboxylase $\mathrm{I}$ vol. of frozen bacteria was suspended in 3 vol. of $0.05 \mathrm{M}-\mathrm{K}$ phosphate buffer, $\mathrm{pH} 7 \cdot 0$, and treated in an MSE ultrasonic disintegrator (MSE model $60 \mathrm{~W}$ ) for 2 min at $\mathrm{O}^{\circ} \mathrm{C}$ (power output $60 \mathrm{~W}$ at $25 \mathrm{kHz}$ ). For the measurement of $\gamma$-glutamylmethylamide synthetase and $N$-methylglutamate synthetase one volume of frozen bacteria was suspended in three volumes of $0.0 \mathrm{I} \mathrm{M}-\mathrm{K}$ phosphate buffer, $\mathrm{pH} 7 \cdot 0$, containing: methylamine, I mM; $\mathrm{Na}$ glutamate, I mM; $\mathrm{MnCl}_{2}$, I mM; dithiothreitol, I mM; and $\mathrm{Na}_{3}$ ATP, I mM. The presence of these compounds in the buffer during preparation of the extracts stabilizes the activity of $\gamma$-glutamylmethylamide synthetase. This suspension was passed twice through a French pressure cell. Unbroken organisms and debris were removed by centrifugation at $20000 \mathrm{~g}$ for $30 \mathrm{~min}$.

\section{Enzyme assays}

Hydroxypyruvate reductase (EC. I. I. I.29) was assayed aerobically at $\mathrm{pH} 4.5$ by the method of Large \& Quayle (1963). Phosphoenolpyruvate carboxylase (EC. 4.I.I.3I) was assayed by the method of Large, Peel \& Quayle (1962), which measures the phosphoenolpyruvate-dependent fixation of $\left[{ }^{14} \mathrm{C}\right]$ bicarbonate, except that the $\mathrm{pH}$ of the assay mixture was 8.6 instead of $7 \cdot 5 . \mathrm{N}$-Methylglutamate synthetase was assayed by the method of Shaw \& Stadtman (1970). $\gamma$-Glutamylmethylamide synthetase was assayed by a modification of the method of Kung \& Wagner (1969). The reaction mixture contained $\mathrm{Na}$ glutamate, Io $\mu \mathrm{mol} ; \mathrm{MnCl}_{2}, 5 \mu \mathrm{mol}$; $\mathrm{Na}_{3} \mathrm{ATP}, 5 \mu \mathrm{mol}$; dithiothreitol, Io $\mu \mathrm{mol}$; [ $\left.{ }^{14} \mathrm{C}\right]$ methylamine, $5 \mu \mathrm{mol}(0.05 \mu \mathrm{Ci} / \mu \mathrm{mol}) ; \mathrm{K}$ phosphate buffer, $\mathrm{pH} 7.0,100 \mu \mathrm{mol}$; and extract in a total volume of $\mathrm{I} \cdot 0 \mathrm{ml}$. The reaction mixture was incubated for $\mathrm{I} h$ at $37{ }^{\circ} \mathrm{C}$ and then $0 . \mathrm{I} \mathrm{ml}$ of $30 \%$ trichloroacetic acid was added to stop the reaction. The mixture was centrifuged and $0.4 \mathrm{ml}$ of the supernatant solution was applied to a small column $(5 \times 25 \mathrm{~mm})$ containing Dowex $50\left(\mathrm{H}^{+}\right)$cation exchange resin. The column was washed with $2 \mathrm{ml}$ of water and the $\gamma$-glutamylmethylamide synthesized in the reaction was eluted with $2 \mathrm{ml}$ of $2 \mathrm{~N}-\mathrm{NH}_{4} \mathrm{OH}$. The entire $2 \mathrm{ml}$ of the $\mathrm{NH}_{4} \mathrm{OH}$ eluate was added to $10 \mathrm{ml}$ of Bray's solution (Bray, 1960) and counted in a liquid scintillation counter. Correction for background and non-specific radioactivity from the column was made by carrying a boiled enzyme control through the entire procedure.

The activities of all the enzymes are expressed in milli-units (mu), where I mu catalyses the transformation of I nmole of substrate in I min.

\section{RESULTS}

The incorporation of $\left[{ }^{14} \mathrm{C}\right]$ methylamine by intact cells of Pseudomonas AMI

When methylamine-grown Pseudomonas AM I was incubated with radioactive methylamine for short periods of time most of the radioactivity was found in serine at the earliest time period $(5 \mathrm{~s})$. Table $I$ shows that smaller amounts of radioactivity were found in 


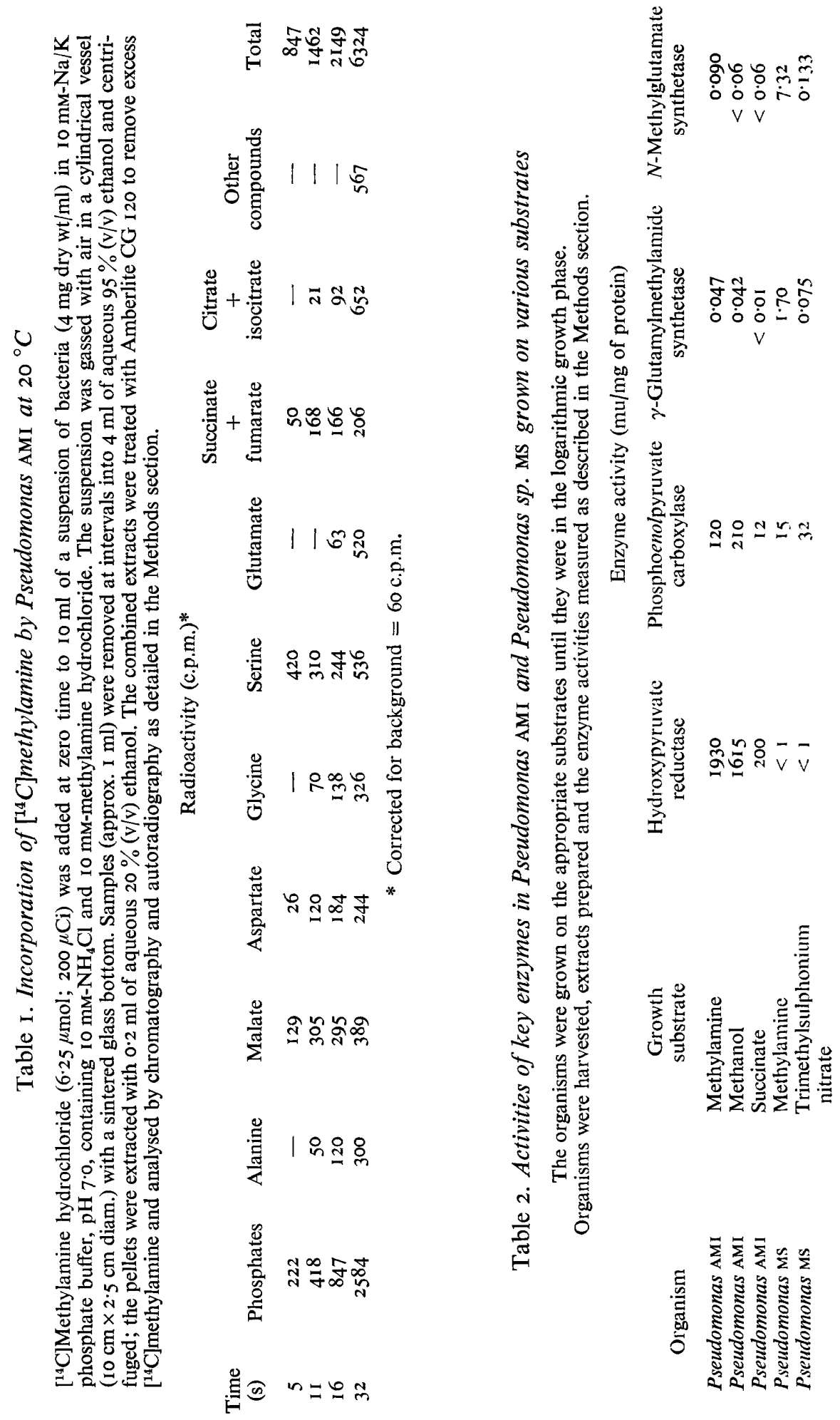




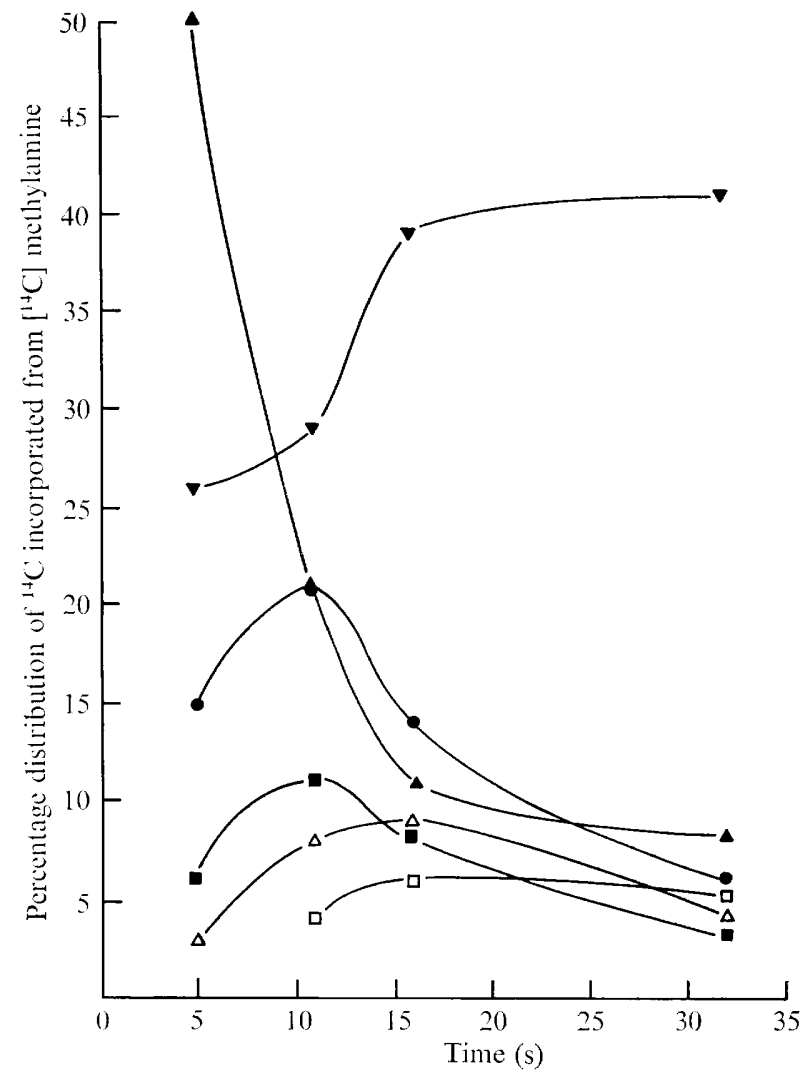

Fig. I. Variation with time of the percentage distribution of ${ }^{14} \mathrm{C}$ incorporated from $\left[{ }^{14} \mathrm{C}\right]$ methylamine into the constituents of the ethanol-soluble fraction of Pseudomonas AMI growing on methylamine at $20^{\circ} \mathrm{C}$. $\boldsymbol{\nabla}$, Phosphorylated compounds;, , malate; $\triangle$, aspartate; $\square$, glycine;

$\Delta$, serine; $\mathbf{n}$, succinate + fumarate.

phosphorylated compounds and dicarboxylic acids. Upon further incubation (Fig. I) the percentage of radioactivity found in serine decreased while that of malate and aspartate first increased and then decreased. These results are very similar to those obtained using $\left[{ }^{14} \mathrm{C}\right]$ methanol (Large et al. 196I). There was no evidence for any formation of either $\mathrm{N}$ methylglutamate or $\gamma$-glutamylmethylamide.

\section{Enzyme activities in Pseudomonas AMI and Pseudomonas MS}

Previous work has established the presence of high levels of hydroxypyruvate reductase in methanol- or formate-grown Pseudomonas AMI (Large \& Quayle, I963). This enzyme is also present at high specific activity in extracts of methylamine-grown Pseudomonas AMI (Table 2), whereas in methylamine-grown Pseudomonas ms no such activity could be detected. This contrasts with the distribution of $N$-methylglutamate synthetase and $\gamma$ glutamylmethylamide synthetase, both of which are virtually absent in Pseudomonas AMI. but present in methylamine-grown Pseudomonas MS. In trimethylsulphonium-grown Pseudomonas MS, however, none of the three enzymes was present in more than trace amounts.

A further difference between the two organisms is manifest in the activity of phosphoenolpyruvate carboxylase (Table 2). The specific activity of this enzyme in methylamine- 
grown Pseudomonas MS is similar to that in succinate-grown Pseudomonas AMI, whereas growth of the latter organism on methanol or methylamine increases the specific activity I8- or Io-fold respectively.

\section{DISCUSSION}

The results obtained in this study confirm the predictions based on the growth characteristics of mutants that the pathway of carbon assimilation operating during growth of Pseudomonas AMI is the same on methylamine as on methanol or formate. There is no evidence either from the whole organism isotope experiment or the enzyme content of the organisms for the involvement of $\mathrm{N}$-methylated amino acids as intermediary metabolites. On the basis of isotopic evidence, organism PAR also uses the serine pathway for growth on methylamine (Leadbetter \& Gottlieb, 1967).

It is clear that Pseudomonas MS grows on methylamine by a pathway which differs in several respects from the serine pathway. The initial fixation of methylamine carbon results in methylation of glutamate to $N$-methylglutamate and $\gamma$-glutamylmethylamide. If these $N$-methylated amino acids function merely as intermediate $\mathrm{C}_{1}$ carriers, the crucial steps of net biosynthesis being similar to those in Pseudomonas AMI, the fact that Pseudomonas Ms lacks hydroxypyruvate reductase would point to a difference in the way in which the carbon skeleton of serine is converted to glycolytic intermediates such as phosphoglycerate.

Pseudomonas MS grown on trimethylsulphonium salts differed again. Hornig \& Wagner (I968) showed that incubation of trimethylsulphonium-grown Pseudomonas Ms with $\left[{ }^{14} \mathrm{C}\right]$ trimethylsulphonium chloride resulted in early labelling of serine, glycine and alanine; no radioactive $N$-methylglutamate or $\gamma$-glutamylmethylamide was detected. The absence of the $N$-methylated amino acids is consistent with the negligible activities of $N$-methylglutamate synthetase and $\gamma$-glutamylmethylamide synthetase in extracts. As in the case of the methylamine-grown Pseudomonas MS no hydroxypyruvate reductase could be detected in the organism when grown on trimethylsulphonium salts. It is not clear from these data to. what extent the carbon assimilatory pathways differ for methylamine and trimethylsulphonium salts in Pseudomonas Ms. It would, however, be remarkable if the organism possessed two pathways of $\mathrm{C}_{1}$ assimilation which were fundamentally, rather than superficially, different.

This study was supported in part by Grant no. GB-6084 from the National Science Foundation, U.S.A., to C.W. We thank Mr A. A. Hancock for his skilled technical assistance.

\section{REFERENCES}

Anthony, C., Dunstan, P. M. \& Drabble, W. T. (197I). Metabolism of $\mathrm{C}_{1}$ and $\mathrm{C}_{2}$ compounds by Pseudomonas AM I: a glycerate kinase mutant and a mutant defective in glyoxylate formation from $\mathrm{C}_{1}$ compounds. Biochemical Journal I25, 66-67P.

BraY, G. A. (1960). A simple efficient liquid scintillator for counting aqueous solutions in a liquid scintillation counter. Analytical Biochemistry I, 279-285.

Gross, D. (1959). High-voltage paper electrophoresis of organic acids and determination of migration rates. Chemistry and Industry I 219-1 220.

HARder, W. \& QuAyle, J. R. (I97I). Aspects of glycine and serine biosynthesis during growth of Pseudomonas AM I on $\mathrm{C}_{1}$ compounds. Biochemical Journal $\mathbf{1 2 1}, 763-769$.

Heptinstall, J. \& Quayle, J. R. (1970). Pathways leading to and from serine during growth of Pseudomonas AM $\mathrm{I}$ on $\mathrm{C}_{1}$ compounds or succinate. Biochemical Journal $\mathbf{1 x 7}, 563-572$.

HorNig, D. \& WAGNER, C. (1968). Utilization of one-carbon units: methylene $\mathbf{H}_{4}$-folate reductase from Pseudomonas MS. Bacteriological Proceedings, p. 1 I 5. 
Kung, H. (1969). Utilization of one carbon unit: metabolism of methylanine by Pseudomonas Ms. Ph.D. Thesis, Vanderbilt University, U.S.A.

KUNG, H. F. \& WAGNER, C. (I969). $\gamma$-Glutamylmethylamide. A new intermediate in the metabolism of methylamine. Journal of Biological Chemistry 244, 4I 36-4I40.

Kung, H. F. \& WAGNeR, C. (1970). Oxidation of $\mathrm{C}_{1}$ compounds by Pseudomonas sp. Ms. Biochemical Journal I16, 357-365.

Large, P. J., Peel, D. \& Quayle, J. R. (196I). Microbial growth on $\mathrm{C}_{1}$ compounds. 2. Synthesis of cell constituents by methanol- and formate-grown Pseudomonas AM I, and methanol-grown Hyphomicrobium vulgare. Biochemical Journal 8I, 470-480.

Large, P. J., Peel, D. \& Quayle, J. R. (1962). Microbial growth on $\mathrm{C}_{1}$ compounds. 4. Carboxylation of phosphoenolpyruvate in methanol-grown Pseudomonas AM I. Biochemical Journal 85, 243-250.

LARGE, P. J. \& QuaYle, J. R. (I963). Microbial growth on $C_{1}$ compounds. 5. Enzyme activities in extracts of Pseudomonas AM I. Biochemical Journal 87, 386-396.

LeAdBetTeR, E. R. \& GottlieB, J. A. (1967). On methylamine assimilation in a bacterium. Archiv für Mikrobiologie 59, 2 I I-2I 7 .

Myers, W. F. \& Huang, K. (1969). In Methods in Enzymology, vol. I3, pp. 43I-434. Edited by J. M. Lowenstein. New York and London: Academic Press.

Shaw, W. V. \& Stadtman, E. R. (1970). In Methods in Enzymology, vol. I2, pp. 868-873. Edited by H. Tabor and C. W. Tabor. New York and London: Academic Press.

Shaw, W. V., Tsai, L. \& Stadtman, E. R. (1966). The enzymatic synthesis of $N$-methylglutamic acid. Journal of Biological Chemistry 24r, 935-945. 